Published in: Creativity and Innovation Management, Vol. 12(2), 2003, p.121-128.

\title{
Coping with chaos in change processes
}

\author{
Klaasjan Visscher and Arie Rip
}

In their efforts to change organizations, managers and change consultants are time and again confronted with the limited controllability of organizations, the complexity and indeterminacy of change processes and the uncertain and ambiguous effects of their actions. In short, they are confronted with chaos. Some managers and consultants try to enhance their (illusion of) control over organizations by attempting to reduce chaos, while others accept and embrace chaos and base their change practice on it. This article focuses on the second group. Based on a study of literature and a series of interviews with experienced change consultants, a typology is developed, in which an enlightened modern, an ironic, and a postmodern way of coping with chaos in change processes is elaborated. The typology may help change consultants and managers with the development of their way of working and the articulation of their professional identity.

\section{Introduction}

"One wing-beat of a butterfly may cause a storm at the other end of the world. Is your commercial talent remarkable enough to make an enormous impact?” With this slogan, printed on flyers and posters, Procter \& Gamble tried to attract Dutch students to attend its 1999 business course. It used an icon of chaos theory, but turned its meaning upside down. According to chaos theory, butterflies may cause a storm, but not because they have a remarkable talent for causing storms and try to have meteorological impact. Through its ad, Procter \& Gamble reinforced the widespread modernist view that changes in organizations are caused by actions of remarkable men and women who want to make a difference, despite chaos and contingencies.

Managers, especially top-managers, tend to treasure the view that their talents and interventions can have a significant impact on the future of an organization. They cherish their agency, or their ability to make a difference, and regard themselves as the principal change agents in their organizations. However, as change agents they are time and again confronted with the limited controllability of organizations, the complexity and indeterminacy of change processes and the uncertain and ambiguous effects of their actions. To cope with these problems, managers increasingly hire change consultants to assist them in reducing chaos and realizing changes.

What should consultants do if they are hired to assist managers in these change processes? They could try to reduce chaos and reinforce their client's self-image, because managers have to manage, and therefore have to believe unconditionally in the effects of their actions. Or they could embrace chaos, advise modesty, and help managers in a different way to change their organizations. This article focuses on consultants who have chosen for the second route. These consultants do not try to reduce chaos for their clients in order to enhance their illusion of control. Rather they accept and embrace the chaos of change processes and base their consultancy practice on it. In this article, we develop a typology of change agents, presenting different ways of coping with chaos in change processes. This typology is based on a study of literature and a series of in-depth 
interviews with experienced change consultants. The typology may help change consultants with the development of their way of working and the articulation of their professional identity. Besides, it may be used by managers to reflect on their approach to organizational change and their identity as a change agent, as well as to find appropriate consultants to assist them in change processes.

\section{The illusion of agency}

Managers tend to think highly of their own agency. Especially when things go well, they are inclined to think that it was they who made the difference, while when things go wrong they blame external factors such as economic depressions, stubborn employees or just bad luck. The view of managers as agents, steering the course of history of an organization, is reinforced and cherished by business press journalists, management gurus and academics involved in the modernist management discourse. They attribute to managers the capacity to change organizations, and sometimes the world around as well, by purposeful action.

The modernist view of change agents and change processes is as follows: Based on an analysis of the opportunities and threats in the market and the strengths and weaknesses of their organization, combined with their experience-based intuition, managers create a vision and a hierarchy of strategic plans. The 'vision' is a statement of what is good for the organization, typically in terms of markets to serve, products to make, growth to realize and resources to employ. Once this vision is established, it soon acquires the status of a 'grand narrative' (Lyotard, 1984), stating what makes sense and what does not, defining success and failure, and what is to be regarded as progress or decline. Directed by this vision, managers make all kinds of plans, ordered hierarchically, to align the organization with the new vision. Once plans are established, managers direct the implementation in the organization, thus realizing the vision. Managers make a difference by creating a vision, making plans and implementing them. Consultants make a difference, in the modernist view, if they can contribute to this process. They may conduct SWOT-analyses, perform benchmarking studies, design elaborated plans, mobilize people to implement the plans, and help to prevent and overcome possible resistance in the organization. Based on their skills and expertise they contribute to the change process, reducing chaos and assisting the management to lead their organization to success, and thus showing their agency as a consultant.

It is an illusion to think that this kind of agency is conclusive to change organizations. The impact of purposeful actions is uncertain and mostly limited, and the sense these actions make depend on the viewpoint of the one who judges them. The relations between visions, plans and effectuated changes in an organization are ambiguous, as is the role of managers and consultants. The complexity and uncontrollability of social processes, the contextuality of order and the narrative character of agency make the modernist view of change processes and change agents appear as illusory.

In order to elaborate this point more generally, consider the Battle of Borodino, as described by Tolstoy in War and Peace (Tolstoy, 1982; see also Latour, 1988). On 26 
August 1812, a battle was fought between Napoleon's troops and the Russian army, near the Russian village of Borodino. On and around the battlefield is a tangle of action. Soldiers act in response to the concrete events that happen to them. Neither the causes, nor the effects of these events are known to them. They cannot see the contours of the battlefield, they do not know the strategies of their generals and they have no idea whether they are winning or losing the battle. In the course of the battle it becomes clear that the actions of some small groups of soldiers are decisive, even though major charges are without any clear result. The commanders present, Napoleon Bonaparte and the Russian field marshal Kutuzow, have no overview over the battlefield and they are constantly troubled by contradictory messages and outdated plans of their general staffs. The messengers they send out with orders for their men rarely arrive at the right spot, and if they do, their message is misinterpreted or ignored. Tolstoy describes the battle as a muddled ball of fighting people, which neither commander can influence. The battle evolves unstructured, unpredictable and uncontrollable, and the influence of individuals with strategic and tactical plans is very small.

Social processes, on battlefields as well as in organizations, are chaotic. Outcomes are emergent and rarely the result of someone's great vision, well-elaborated plans and careful implementation efforts. The stream of events is without an a priori structure. During and after the action, people try to bring order into the events by telling stories about them. "Man [...] is the story-telling animal. Wherever he goes he wants to leave behind not a chaotic wake, not an empty space, but the comforting marker-buoys and trail-signs of stories" (Swift, 1984, p.62). In a story, an unstructured stream of events gets a beginning and an end, with certain persons and actions singled out. Separate actions are made visible and receive meaning in light of a plot. Causes are attributed to circumstances and people with intentions. A story tells whether something has changed, what has changed, who has made a difference and why. From the muddled ball of events and actions, storytellers pull threads and weave them into a meaningful whole.

"Even though stories are the inevitable results of action, it is not the actor, but the storyteller, who perceives and 'makes' the story" (Arendt, 1958, p.192). Stories are the accomplishment of storytellers and are not determined by the events. However, storytellers are to a certain extent bound to the rules of a discourse to tell their stories acceptably and convincingly. Reducing the complexity and contingency of the events by attributing agency to only a few purposeful acting individuals is a central rule in modernist discourse. As the mainstream of $19^{\text {th }}$ century historians told their audience that Napoleon and Kutuzow won battles with their ingenious strategies, journalists, management gurus, executives and academics tell us that successful organizational changes are achieved through the brilliant strategies of talented managers, the Napoleons of our time. Formulated strategies and statements of CEOs are highlighted as the sources of success. Management storytellers reconstruct 'actual' strategies in hindsight from the changes that have taken place. And especially when managers and consultants anticipate a reconstruction, they may produce so many documents and statements, which may be interpreted in so many different ways, that it is almost always possible to reconstruct a suitable strategy or plan retrospectively. 
Managers may have different reasons for reinforcing modernist discourse and maintaining the illusion of agency. It helps them to justify their position to shareholders, so to mobilize financial and other resources for their plans. It fulfils the expectations of employees, external stakeholders and the public, gives them recognition, and strengthens their self-confidence and self-esteem. Consultants may also have reasons to maintain the illusion of agency. It helps them to show their added value, since they can make a clear contribution to strategy formulation, organization design or implementation. Besides, one can earn a lot of money in this kind of management consultancy. But once a manager or a consultant has acknowledged the chaotic character and uncontrollability of change processes, the discourse dependent attribution of agency, and the limited and ambiguous effects of the process of making and implementing strategic plans, they cannot maintain the illusion of agency and have to find ways to cope with the unpredictability and complexity of the world, without the help of modernist storylines.

Those consultants and managers cannot view a strategy as a 'grand narrative' anymore, the rationally established and indisputable basis for all justifiable plans. Strategies are fragile narrative constructions, and their definitions of progress and decline are contingent, bound to the specific context in which the strategy has been created. This also problematizes the hierarchy of plans and the implementation process. People with different opinions cannot simply be regarded as obstacles to progress. They view the process from a different context, which may be justifiable as well. Strategic change may involve the suppression of other people, while the justification for doing so can only be built, at best, on quicksand.

To summarize the preceding we formulate three characteristics of the change process that are especially relevant for the actions of change agents, viz. 'chaos', 'attribution' and 'contextuality'. 'Chaos' is our shorthand to indicate that order emerges without there being an a priori structure, and that the actual changes are established in the complex course of the process. 'Attribution' indicates that the relation between effects and the actions of individuals is not a direct, causal one, but that this relation is created by storytellers, in stories where effects are attributed to actions and persons. 'Contextuality' means that the sense and the value of any action and any order is bound to a certain context and can be valued differently from different points of view. These characteristics show that agency is to a certain extent illusory, but also how an illusion of agency can occur. Agency is created in stories; it is not an 'ability to make a difference', which a change agent may or may not possess.

\section{A typology of change agents}

If 'chaos', 'attribution' and 'contextuality' are acknowledged, and not seen as something to be overcome or reduced, there are still several positions possible. Taking 'contextuality' as a starting point, three positions are possible: an enlightened modern, an ironic, and a postmodern position. The enlightened modernist assumes that there are situations where the 'contextuality' of actions and order can be bracketed and where processes can be seen as determinate. In these situations, a modernist approach is thought to be possible. The ironist acknowledges 'contextuality', but participates in processes in 
which local and temporary certainties and stabilities may emerge (Rorty, 1989). The postmodernist sees everything as contextual and indeterminate - "anything goes" - and refrains from attempts to bring about order.

Taking one of these positions on 'contextuality' has consequences for the positions on 'chaos' and 'attribution'. In practice, change agents tend to develop a coherent and consistent way of coping with all characteristics of the illusion of agency. Enlightened modernists look for situations where they can set the illusion of agency aside. There they take normative positions, based on expertise and rational analysis, act intentionally to change organizations and claim the credits for successes. But they admit that it happens to be a fortunate accident that it is possible in some situations. Ironists see agency as an attribution after the fact, produced through actors who aim to make a difference. They can involve themselves in attempts to realize changes and claim credits without believing in the determinate character of such processes. Ironists show what they want to achieve and what they stand for, but they remain sensitive to alternative viewpoints and stories, and willing to be challenged in their temporary and local certainties. Postmodernists cherish the plurality of stories and views, and refrain from attempts to effect change by purposeful interventions. They only create reflexiveness among the participants in change processes.

\section{Methodology}

This typology concerns both change consultants and managers who operate as change agents. To elaborate the types empirically, a series of in-depth interviews has been conducted with change consultants, in order to reconstruct the ways they work and cope, as part of their professional identity. We focused the interviews on change consultants rather than on managers, because we expected them to have elaborated a way of working and a professional identity, independent of the specifities of particular organizations. And since they are hired to assist in changing organizations, and have to win contracts, they have articulated their way of working and can present 'who they are'. Furthermore, consultants are not only confronted with the illusion of their own agency, but also with the illusion of agency of their clients, and that makes it essential for them to be reflexive about the way they cope with illusions of agency.

To acquire relevant data we interviewed seven senior consultants, who had shown in publications or otherwise that they recognized the problems and dilemmas with the illusion of agency. In the interviews, the consultants were not directly asked to state their way of coping with the aspects of the illusion of agency and their professional identity. We started with questions about their normal practice, asking them to tell typical stories about their way of working, through their own eyes, and through the eyes of clients and colleagues, since identities are constructed in and through concrete stories by different storytellers. Then, focussing on the agency-related dilemmas they did or would encounter, we asked them to reflect and to reconstruct their ways of coping. The following descriptions of the three types are illustrated with examples and (translated) quotations from the interviews. 


\section{Enlightened modernists}

Enlightened modernists cope with 'chaos' by lumping and splitting. This means that they distinguish between chaotic, uncontrollable situations, in which they do not work, and controllable situations, where 'chaos' can be bracketed. In the latter, purposeful action is possible and results can be obtained. Enlightened modernists only engage themselves with problem fields where they can define the problem and the criteria for success, where they have a lot of experience and well-elaborated methods. There they have a reasonable chance for success. A consultant said, “I wouldn't say to a client that our way is the only way, but we have experience with it and we achieve good results with it, and if that appeals to the client, we sell it." In many cases, enlightened modernists have specialized in fields of organizational change with a history in industrial engineering, such as logistics or administrative organization.

For enlightened modernists, it is of the utmost importance to be able to demonstrate that their actions have results, because their clients hired them for achieving results and will judge their added value on this. Therefore they try to obtain the role of expert in the stories of their clients and to receive the credit for (some of) the changes that take place in an organization. One consultant remarked that it is therefore important that some results and successes become visible in the short term. Otherwise, clients will probably forget the impact of the consultant. Enlightened modernists reinforce the view of the change process as a rational design process, make a visible contribution to this process preferably in the form of a written text with their name attached to it - and propagate stories about the process that acknowledge their agency.

Enlightened modernists take normative standpoints towards their clients, telling them what is good for them, based on experience, rational analyses and knowledge of the market, competitors and management literature. According to enlightened modernists, clients expect answers from them. Clients want certainty and consultants think themselves able to provide it. As one of the consultants said: "They know, because they tried to get things started for a while, that it is very difficult, that it will cost people their head and that careers are heavily dependent on the success of such a project. So what do they seek: certainty. They talk with people, and the consultant or firm that gives them the idea that 'they can solve our problem' is hired." Enlightened modernists help create strategies with a clear notion of progress and success, which is not to be doubted within the organization, gives sense to all kinds of plans and justifying the implementation. Giving clarity and certainty is of the utmost importance. Not showing uncertainty is considered even more important. A consultant said: "One might ask: how sure are we [the consultants] that we are on the right track? Well, we do not know for sure that we are on the right track. But we are sure of this: it is better to have a somewhat inferior plan than no plan at all. So you should make a plan, and you can think it over a hundred times, and there will always be better plans, but in the end it is about creating certainty, giving everyone a marching route.” 


\section{Ironists}

Ironists cope with 'chaos' by using 'guerrilla methods'. This means that they do not try to bring about change in organizations in a controlling manner, as do enlightened modernists, but by creating occasional incentives, tackling local problems and removing bottlenecks. Their work is not aimed at reaching a desired end-situation, but at escaping from an undesirable current situation. They initiate changes and start looking for solutions in constant interaction with their clients and other members of the client organization, mixing process-oriented and outcome-oriented techniques.

Ironists have a more process-oriented view of organizational change than enlightened modernists. Organizations are seen as emerging patterns, potentially developed in a collaborative learning and sense-making process. Changing organizations is a prototyping process, a constant conversation with the situation, an alternation of doing and learning. In the process, a balance is sought between intervening and self-organization, between designing and letting emerge. One of the interviewees phrased his relation to design metaphorically: “I fly around 'design' like a moth around a flame. I couldn't do without it, because that would be the end of my profession, but I know that, if I come too close, my wings will burn.”

Ironists are aware of the fact that agency can be attributed to people in different ways. Different stories are possible, but, nevertheless, ironists try to make their own story, looking for causes of success and failure with themselves and with the organization. They bring order into the situation, but recognize the fragility of this order. But if they would not try to do that at all, they would not be able to learn from their experiences. And especially in cases of assumed failure, this is important. Several interviewed consultants stressed that it is important to frame failure as a learning experience, because otherwise consultants would entirely loose their self-confidence and trust in their agency.

Ironists have a different view of their impact than enlightened modernists. They think that their main impact is in initiating change processes, not in reaching objectives and achieving good results. The latter would not be possible for ironists because they do not know in advance where the change process will end. They help put things in motion and monitor constantly to see whether an organization is really changing. One of the consultants said about this monitoring: "Because of all kinds of circumstances a consultant may fail to get an organization moving, but it is inexcusable if he only finds out after a year and sending in a bill of a hundred thousand dollars.”

Ironists may take a normative position towards their clients and tell them how the client should act. But they know and show the historical and paradigmatic context from which their standpoints originate. They base their normativity on local certainties, things they think to see clear in a certain place and time. But ironists are aware of the fact that they can be wrong and that they may do damage if they remain attached too strongly to their positions. They are flexible enough to adjust their standpoints if the situation requires it, or if their clients really disagree with them. As an interviewed consultant remarked: "It happens rather often that a consultant thinks 'I know very well how those things go, so don’t nag about alternatives, we should proceed in that direction'. But it is part of your 
flexibility as a consultant to realize that what will really happen in an organization is not what the consultant wants, but what the organization wants." So ironists are more flexible in their opinions and actions than enlightened modernists, but they do have them, in contrast with postmodernists, who totally refrain from taking normative standpoints.

\section{Postmodernists}

Postmodernists cope with 'chaos' by refraining from pursuing goals or initiating changes, thus avoiding the confrontation with the illusion of agency. It is the client who wants changes, who has to cope with 'chaos', not the postmodern consultant. The job of the postmodernist is to mirror the client organization in different ways, showing the premises of their problems and solutions, and to open up opportunities they had not seen themselves. Postmodernists may act as 'reflectors', asking questions to stimulate their clients to reflect. Or they may play the role of 'provocateur' or 'wise fool', who tries, by asking 'naïve' questions and by calling in question what is taken for granted, to challenge the way of thinking of clients, and to show them new perspectives. Genealogical analysis of strategies on a local level may be used as a technique to show clients their strategy in terms of its history and thus its 'contextuality'. They may also use deconstruction techniques, showing the suppressed opposite that is always latently present in a strategy. If, for instance, a client stresses the bright side of a strategy, the postmodernist will show the dark side, if a client emphasizes order, the postmodernist emphasizes chaos.

Postmodernists see that agency cannot be attributed unambiguously, and that impact or a lack of impact, success or failure are totally dependent on whom is asked at what moment. Therefore, it is not possible to make any clear evaluation of a change process. Postmodernists do not attempt to evaluate the effects of their work. It is sufficient if they have a good feeling about their work and if their clients keep coming back. Apparently, there are clients who think it pleasant or useful when a postmodernist mirrors their problems or brings up new perspectives. According to one of the interviewed consultants, his clients say he is 'creative'. In this way postmodernists justify their way of working and their 'raison d'être'.

Postmodernists do not take any normative position towards their clients and the organizations. They help their clients by reframing their problems and showing possible solutions, not by telling them what to do. A consultant told us: "As a consultant, you can be useful by helping someone to get another perspective, or several other perspectives. And you don't have to tell what the correct perspective is, because there isn't any. All perspectives are possible, but it is nice to see that some perspectives give someone a bad feeling and other perspectives give him a good feeling.”

\section{Concluding remarks}

Enlightened modern consultants, ironic consultants and postmodern consultants are apparently able to create added value for their clients. They have different ways of working, based on different assumptions, think differently about the status of their opinions and judgments, and expect (and get) different types of credit for their work. 
Table I summarizes their ways of coping with the illusion of agency. This typology makes explicit three aspects of the professional identity of change consultants and its internal coherence. Consultants develop their professional identity in concrete interactions with clients and colleagues. In practice, recurrent types occur, and by putting them in a typology, we have created three models that may help consultants to reflect on these interactions, and to articulate and further develop their identity. It may also make them aware that a positional choice on one of the aspects of the illusion of agency has consequences for their positions on the other two.

\begin{tabular}{|c|c|c|c|}
\hline & Enlightened modernist & Ironist & Postmodernist \\
\hline 'Chaos' & $\begin{array}{ll}- & \text { Bracketing chaos } \\
\text { - } & \text { Elaborate design } \\
& \text { methods } \\
\end{array}$ & $\begin{array}{ll}\text { - } & \text { Fighting and embracing } \\
& \text { chaos } \\
\text { - } & \text { Collaborative learning }\end{array}$ & $\begin{array}{ll} & \text { Avoiding chaos } \\
- & \text { Mirroring the client }\end{array}$ \\
\hline 'Attribution' & - $\quad$ Credits for effects & $\begin{array}{ll}- & \begin{array}{l}\text { Credits for initiating } \\
\text { change processes }\end{array} \\
\end{array}$ & $\begin{array}{ll}- & \text { Credits for 'good } \\
& \text { feeling' or creativity } \\
\end{array}$ \\
\hline 'Contextuality' & $\begin{array}{ll}- & \text { Certainties } \\
\text { - } & \begin{array}{l}\text { Occasional grand } \\
\text { narrative }\end{array} \\
\end{array}$ & $\begin{array}{ll}\text { - } & \text { Local certainties } \\
\text { - } & \text { Personal narratives }\end{array}$ & $\begin{array}{ll} & \text { No certainties } \\
\text { - } & \text { Anything goes }\end{array}$ \\
\hline
\end{tabular}

Table I: Three types of change agents

This typology may be used by managers who want to reflect on their personal way of working and their identity as a change agent, or those who want to hire an appropriate consultant to assist them in a change process. Managers tend to be modernists, but that does not mean that it is impossible for them to act as ironists or postmodernists in change processes. As postmodernists they might operate as if they were outsiders, and leave the change process mostly to the self-organization of their employees, while enhancing their employees' reflexivity and creativity in that process. And as ironists, they might make the change process into a collaborative learning process with their employees and stakeholders, making the changes a joint responsibility. However, managers often have an all-encompassing responsibility for their organization, and the ironist and postmodern rewards for the initiation of change or enhanced creativity may not be enough for them. Besides, they have a history with an organization and cannot shape their identity as a change agent irrespective of their established managerial identity as a whole.

Managers may compensate their own modernism by hiring ironic or postmodern change consultants. If they acknowledge the illusion of agency to a certain extent, by their own conviction or through a consultant's persuasion, a cooperation with ironists or postmodernists may be very fruitful. An interviewed postmodern consultant told that he rather worked with modernist managers than with ironists or postmodernists. Modernists are more likely to get stuck in their own frame of reference, because they do not see its 'contextuality' and are blinded for alternatives, and with them the added value of a postmodernist shows best. Postmodern consultants may also assist postmodern managers in their efforts to increase the reflexiveness of their organization, but a risk is then that consultant and client start deconstructing each other's deconstructions and mirroring each other's mirrors, leading to reflections ad infinitum and no changes at all. Ironic consultants usually work best with ironic managers. They need like-minded partners to walk the uncertain and ambiguous road of change. If ironists work with postmodern managers, who refrain from establishing any order, even locally and temporarily, they 
have to look for partners elsewhere in the organization. In such cases, consultant and client organization are cooperatively working on changes while being mirrored and deconstructed by respectively their client and their manager. Ironic consultants may also work with modernist clients, but then it is extra important to communicate what a manager can expect from them and what they expect from a manager. An interviewed consultant said that modernist managers tend to see ironists as cautious modernists, who just need more information of the situation to provide them with expert advice, certainty, and guaranteed success. If the ambiguity and indeterminacy of the process then prove fundamental, they are disappointed. For those managers an enlightened modern consultant would have been a better match. Enlightened modernists may also work for ironic or postmodern clients, but only in the rare cases where the clients agree that 'chaos' and 'contextuality' can be bracketed. In other areas, ironic and postmodern clients would consider modernist consultants arrogant, naive or overconfident.

In many cases, individual managers and consultants will not fit purely in one of the categories of the typology. They may, in fact, behave like chameleons, changing color in changing contexts. In one context they may show themselves as enlightened modernist, while in another context they appear as ironist. Among the interviewed consultants was an enlightened modernist, specialized in manufacturing strategies, who turned into an ironist when he started to engage himself in making more general corporate strategies. A postmodern consultant, who had no certainties in the organizations of his clients, 'changed color' into an ironist when he started to talk about the consultancy profession. An internal consultant, operating as an ironist, showed up as an enlightened modernist when he had to justify his work to the CEO of the company. 'Changing colors' can occur when the tasks are different, or when the ‘context of justification' is different.

If 'changing color' becomes a conscious strategy, this might be seen as a fourth type: the chameleonic change agent. Such a change agent would need a broad repertoire of skills and stories, and sufficient flexibility to change at the right moment. On a meta-level, one may applaud such flexibility. A postmodernist who is willing to step from behind the mirror to aim for changes is taking up responsibilities. But this flexibility may also be seen as inconsistency. If someone is known as a modernist and switches suddenly to an ironic or postmodern identity, or the other way around, she or he may lose credibility. 'Changing color' can also lead to opportunism. Suppose that a consultant starts as an enlightened modernist, with a rational method, a perspective of bright results, and with a storyline to claim the credits for these results. But when things go wrong, she or he changes into an ironist, and says she or he only wanted to set the organization in motion, and it is the client, not the consultant, who is responsible for the results of the organization. The other way around, a consultant could start as an ironist, but, when things work out well, try to claim the credits for the success. This kind of chameleonic behavior occurs, definitely, but it should not be considered a fourth type to be added to the typology. The 'chameleonic change agent' does not specify another way of coping with 'chaos', but refers to the consistency and flexibility of the change agent in action and identity. 
Referring to the Procter \& Gamble advertisement, we could say that, in a way, change agents are like butterflies. They may have great impact, but then again they may not. They should not overestimate their ability to influence the success of organizations. The change agents we interviewed did not do so. They accepted that the effects of their actions are mostly limited, uncertain and ambiguous, and that they may not take their agency for granted. Enlightened modernists can see the possibility of guaranteeing some success, but only in contexts where they think 'chaos' can be bracketed, and even then success is precarious. But that does not mean that change agents who accept 'chaos' cannot produce any added value for an organization. On the contrary, but their added value shows in the change process itself and not in its results.

\section{References}

Arendt, H. (1958) The human condition. The University of Chicago Press, Chicago, USA.

Latour, B. (1988) The pasteurization of France. Harvard University Press, Cambridge, USA.

Lyotard, J.F. (1984) The postmodern condition: a report on knowledge. Manchester University Press, Manchester, UK.

Rorty, R. (1989) Contingency, irony and solidarity. Cambridge University Press, Cambridge, UK.

Swift, G. (1984) Waterland. Picador, London, UK.

Tolstoy, L.N. (1982) War and peace. Penguin Books, Harmondsworth, UK. 